Historic, Archive Document

Do not assume content reflects current scientific knowledge, policies, or practices. 

62.09
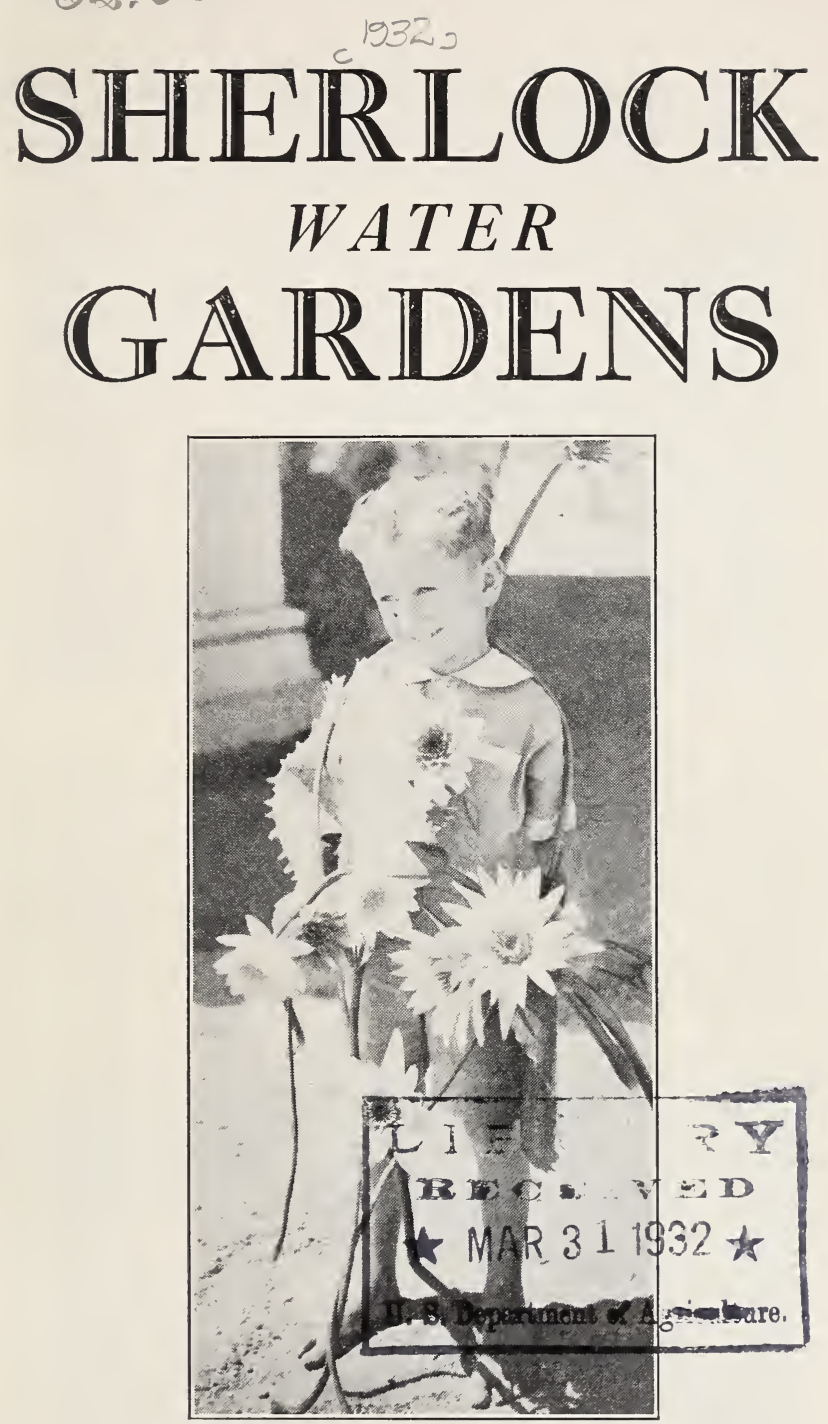

THE SMALL BOY AND THE BIG LILIES

PHONE BURBANK $342-J$

2020 N. SAN FERNANDO BLVD.

AT BURBANK-GLENDALE BOUNDRY LINE

GLENDALE, CALIFORNIA 


\section{HARDY WATER-LILIES}

\section{RED, PINK, WHITE, ORANGE, AND YELLOW}

The popularity of this class of Nymphæas has increased so rapidly that some of the varieties can scarcely be propagated in sufficient quantities. It is desirable that order's be sent in early to avoid disappointment, and it is well to indicate what varieties may be substituted when orders are placed late in the season. No winter care is necessary in natural ponds or lakes, and there is nothing more beautiful than a broad expanse of water dotted with the green lily-pads and fragrant blossoms in all shades of red, yellow, orange, white, or pink.

Hardy Lilies are equally at home in concrete pools, half barrels, or tubs; and with a little care to prevent actual freezing of the roots, their beauty and fragrance may be enjoyed year after year. Lack of experience will not interfere with results, as Waterlilies "just grow" when provided with sunlight, rich soil, and warm shallow water.

COMANCHE. A strong-growing variety and the finest of the changeable types. The prevailing color the first day is apricot, deepening later to a rich copper-bronze, streaked with red. It is difficult to describe the effect of these blossoms standing in stately splendor above a field of brown-blotched olive-green leaves-a fitting centerpiece for a formal pool. Usually the first lily of the season to bloom and the last to stop. $\$ 3.50$ each.

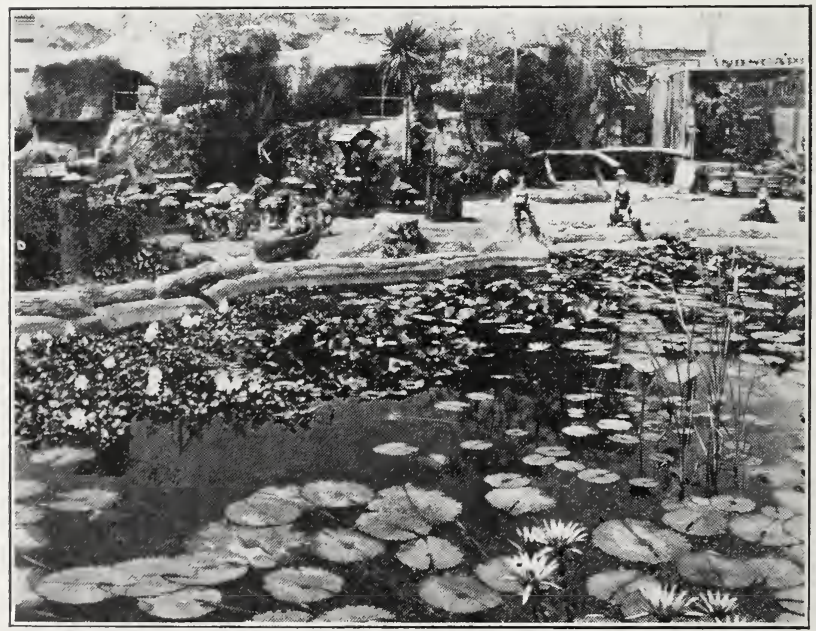

One of the Pools by Our Store 


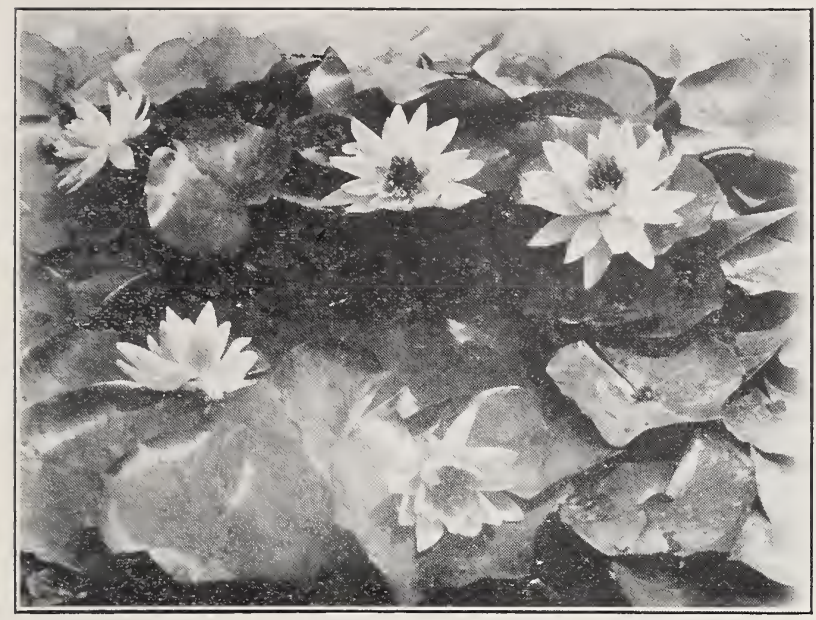

Sun Rise, Finest of All Hardies

MASANIELO. (Marliac, 1908.) The flowers of this variety are very fragrant and in form are all that could be desired of a hardy Lily. The plant is a very free grower and needs considerable room. The flowers are rose-pink, dotted with carmine; the sepals of the bower are white, making a very odd contrast to the color of the petals. $\$ 3.50$ each. 2.50

SOMPTUOSA. This variety of French origin is exceedingly attractive. The flowers are really enormous, very double, and fragrant. The outer petals are rosy pink, gradually deepening toward the center, and lightly spotted with a deeper shade of color. Deep orange stamens complete the color combination of this excellent variety. $\$ 3.50$ each. 3.00

AURORA. Changing hues in the blooms of this plant make it exceedingly interesting. When the flowers first open they are a creamy yellow tinted with rose, which gradually changes to a copper red by the third day. A small plant, suitable for tub-culture or corner of pool. $\$ 1.50$ each.

GLORY. A free bloomer of deep carmine red. Very desirable. $\$ 3.00$ each.

PAUL HARIOT. A magnificent variety, producing flowers of large size, distinctive in color, firm in texture, and lasting in quality. Upon opening the first day, the flowers are clear canary-yellow, the second day they are shaded with pink at the base of the petals, and on the third day this pink suffuses the whole flower. This variety is very free-flowering, grows well under varied conditions, and has met with favor wherever seen. Awarded Society of American Florists' Certificate of Merit. $\$ 2.50$ each. 
ROBINSON. Large, floating flowers of dark orangered. A free bloomer and should be in every collection. $\$ 3$ each.

PYGMY, YELLOW HELVOLA (N. tetragona Helvola.) This is the Chinese Pygmy Waterlily which is best suited for shallow water or tub culture. The flowers are a creamy yellow and sweetly scented. These flowers seldom are more than $1 \frac{1}{2}$ to 2 inches across but are produced freely. Foliage dark green and mottled with brown on top, red underneath. A unique and lovely variety. $75 \mathrm{c}$ each.

MARLIACEA CHIOMATELLA. (Yellow.) Mediumsized flowers usually 4 to 6 inches across. Color of the bloom is bright yellow, with stamens somewhat deeper in color. Leaves green, mottled brown. One of the best. $\$ 1.50$ each.

MEXICANA. A very heavy growing lily with bright yellow flowers standing well out of the water. Very desirable for bordering a pool or tub culture, $\$ 1.00$ each.

GLADSTONE. Flowers of glistening white 6 to 8 inches across. Cup shaped. One of the finest white lilies grown. Should be allowed plenty of room. $\$ 1.00$.

MARLIAC. White flowers, large, of sparkling whiteness. Large plants, free bloomer. $\$ 1.00$ each.

MARLIACEA CARNEA. (Flesh.) A vigorous variety. flowers large, of a soft flesh-pink, deepening toward base of petals. $\$ 1.50$ each.

TUBEROSA ROSEA. .. Flower's of wax texture and exquisite shade of pink, 4 to 5 inches across, standing well out of the water, wonderfully scented. $\$ 1.50$ each.

CONQUEROR. This grand variety is one of the finest of the hardy lilies. The flowers are 8 to 9 inches across and dark carmine red in color, the petals flecked with white, sepals lighter. Flowers from early in the spring to late in the fall. $\$ 5.00$, etc. 3.50

ESCARBOUCLE. A most attractive and meritorious variety. The flower's are most striking in color, being a uniform vermillion-red. A free bloomer and a strong grower. Sure to become popular. \$6 each. 5.00

SUN RISE. We consider this one of the finest hardy lilies grown. Flowers immense bright sulphur yellow in color, star like in shape and very double. Leaves large sreen mottled slightly with brown. Blooms nearly the entire year in Sou. Calif. We have a limited stock to offer at $\$ 7.50$, etc. S. 00

JAMES BIYYDON. Flower is a lovely cup-shaped, bright crimson. The under side of the petals have a silver sheen. The plant is a strong, continuous bloomer. $\$ 3.00^{-}$each.

2. 50 
EUGENIA DE LAND. This grand variety belongs to the N. odorata group and is unequalled by any other by the same genus. Flowers extra large of true $\mathrm{N}$. odorata type, floating petals long and lanceolate; color an exquisite shade of deep rose-pink of iridescent hues, with yellow stamens. Vigorous and free flowering in a natural planting. $\$ 2.00$ each.

GLORIOSA. Deep red flowers 5 to 6 inches across. Plant compact and of moderate growth; very free-flowering. The most popular red water lily. $\$ 5.00$ each.

MRS. RICHMOND. A rare variety of singular beauty. Very large flowers of deep rose with lilac tints. Petals broad and full, as befits an eight inch flower. Stamens a delicate canary-yellow. Rare and extremely choice. $\$ 25$.

LUCIDA. A free grower and good bloomer. Flowers are large, star shaped; rose vermilion fading to darker center with yellow stamens, making a wonderful coloring in a water lily. Leaves blotched reddish brown. Each $\$ 2.50$.

THE NELUMBIUM (Nelumbo) or Sacred Lotus. It is not difficult to understand the reverential admiration of the ancients for this plant as we view its great shildlike leaves several feet across, carried high above the water, its fragrant blossoms like gigantic roses, and its curiously shaped and colored seed-pods, all arising in perfect beauty from the mud in the depths of the pond.

We offer the following choice varieties: White dormant tubers, $\$ 1.50$; in tub, $\$ 5.00$. Flame Pink dormant tubers, $\$ 3.50$; in tub, $\$ 7.50$.

$$
2.50 \quad 5.00
$$

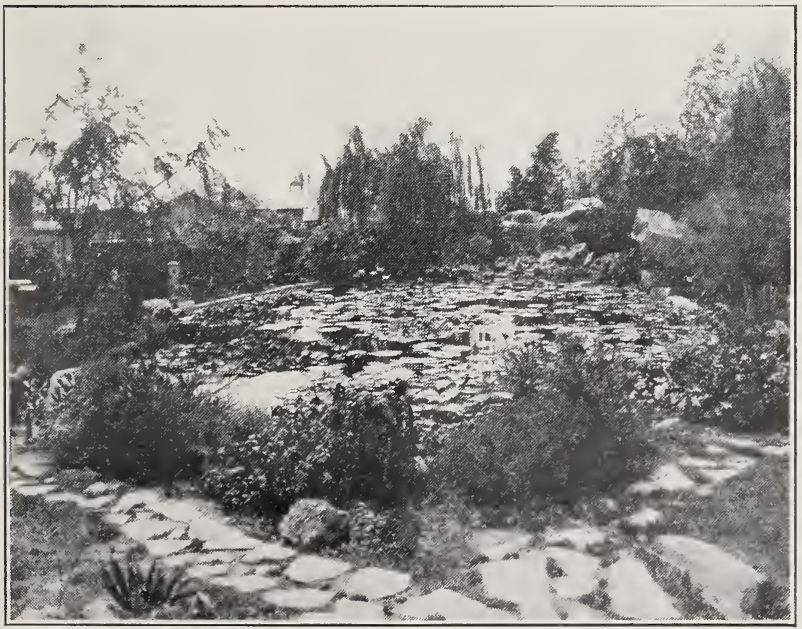

"A Little Bit of Heaven" At Our Display Grounds 


\section{TROPICAL WATER-LILIES}

\section{BLUE, LA VENDER, PUIPLE, RED, WHITE, AND PINK}

Tropical Waterlilies or Nymphæas have many desirable qualities. Although they are set out late in the season, usually June to October, they make such remarkable growth that within several weeks blossoms appear, and continue increasing in size and numbers until heavy frosts destroy the foliage. As cold does not cause them to become dormant, the blooming season closes much later than that of the hardy varieties. Three months is a fare averase in northern states. lengthening in the South, and in indoor pools, to the full year where the temperature averages 65 to 70 degrees. The plants are remarkably adaptable and may be made to produce 3 -inch flowers by being crowded into small pots in a bucket of water, or 12-inch flowers and a 6-foot leafspread when planted in a large box in a sunny pool. The blossoms are carried a foot or more above the surface of the water, in pleasing contrast to those of the native or hardy varieties, and because of their lasting fragrance. Make excellent cut flowers.

MRS. C. W. WARD. This splendid variety was produced from N. gracilis. It has the free-blooming characteristics of its parent, but produces a very much larger flower, deep rose-pink-almost red-in color. The stamens are yellow and the flowers rise well above the water. $\$ 2.50$ each.

WILLIAM STONE. This variety was produced from Gracilis. The purple flowers attain a diameter of 5 to 7 inches and have purple stamens and a yellow center. They open early in the morning and do not close until late in the afternoon. They are carried well above the water. Color combines beautifully with Mrs. C. W. Ward. $\$ 2.50$ each.

STELLA GURNEY. A spontaneous seedling, raised in Tower Grove Park, St. Louis. The parentage, recently proved by Pring. determines it a seedling from Mrs. C. $W$. Ward. It is a strong, free-blooming variety. Flowers are above the average in size, light rose-pink. Leaves light green, bearing extremely long petioles. $\$ 2.50$ each.

PENNSYLVANIA. Deep blue flowers a foot across and produced freely. Sepals marked with purple lines and dots. The leaves slightly speckled with brown above; beneath, the ground-color is red-purple at the edge, shading to pale green centers. $\$ 5.00$ each. 


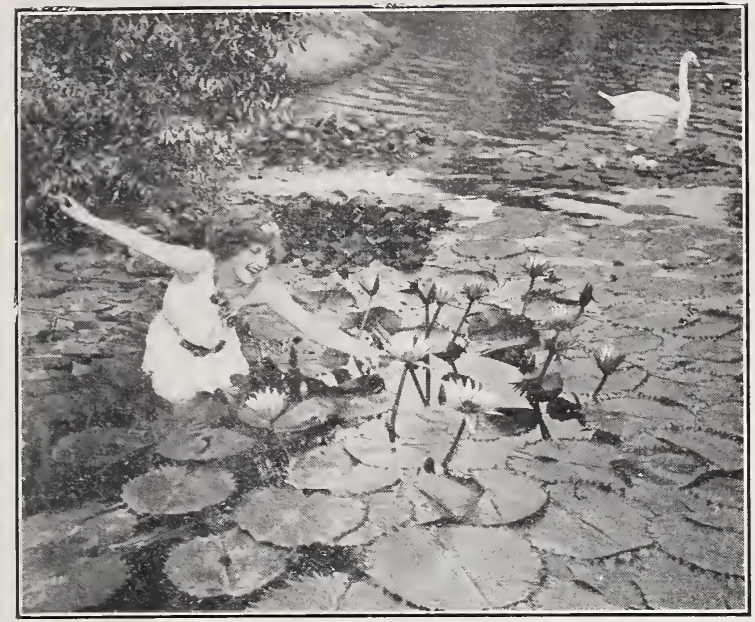

Our Planting at Toluca Lake

PANAMA PACIFIC. This splendid variety is of the ever blooming viviparous type, strong growing and free flowering. The buds as they come out of the water are bronzy green, spotted with a reddish brown, opening rich rosy red which is quite pronounced in the full sun. When fully opened the predominant color is reddish purple and the stamens are yellow. This is a new and distinct color in water lilies. An excellent variety for the conservatory in winter, $\$ 5.00$ each.

ZANZIBARENSIS RUBRA. Splendid variety bearing flowers of very bright rosy-crimson. An extremely free bloomer. Each $\$ 5.00$.

ZANZIBARENSIS PUIPUREA. Rich, dark blue flowers are produced on long stems. Continuous bloomer. Each $\$ 2.50$.

'ZANZIBARENSIS ROSEA. Similar to above. Color a deep rosy-pink. Each $\$ 2.50$.

\section{SMALL AQUATIC PLANTS}

WATER HYACINTH (Eichhornia crassipes major.) Shiny dark green leaves, the stems of which are expanded into pseudo bulbs, which serve as ail-chambers. The orchid-like flowers of lavender form a spike like that of the true hyacinth. Propagation is by means of runners at the surface, and the growth is so rapid that navigation is hindered in streams in the southern states where they grow profusely. It is, perhaps, fortunate that the plant is destroyed by frost. The long, bushy roots are excellent for receiving the spawn of goldfish, therefore 
the Water Hyacinth may be used to advantage in pools of fair size. $15 \mathrm{c}$ each, $\$ 1.00 \mathrm{doz}$. $\$ 1.50$ when packed and shipped.

UMBRELLA PALM (Cyperus alternifolius.) Grows well either in small pools or moist ground. $\$ 1$ for 3 , $\$ 2.50$ per doz.

CAT-TAIL (Typha latifolia.) One of the favorite native swamp plants. $\$ 1.50$ per doz. $25 \mathrm{c}$ each.

ARIROWHEAD (Sagittaria sagittifolia.) Distinctive leaves shaped as the name indicates and standing 1 to 3 feet above water. Flowers freely in a series of white spikes. 50 e ค. ค.rh

WATER CRESS. Thrives in sun or shade; ideal near a cold spring. Edible. Rooted plants, $\$ 1$ per doz.

WATER POPPY (Hydrocleis nmyphoides.) The leaves float upon the surface of the water. Flowers are large and yellow, similar to the poppy. It is in flower almost continuously. $15 \mathrm{c}$ each, $\$ 1.00 \mathrm{doz}$.

ANACHARIS (Eloảea canadensis gigantea.) Subaquatic. $\$ 1.50$ per doz. Excellent oxygen plant.

MYRIOPHYLLEM VERTICILLATUM (Popular Green Milfoil.) Very fine leaves, pinnately parted and capillary; color a beautiful soft green. Subaquatic. 50c for $3, \$ 1.50$ per doz.

MYRIOPHYLLUM PROSERPINACOHDES (Parrot's Feather). An aquatic plant having long, trailing stems, covered closely with whorls of most delicate foliage. Planted in a tub or water-tight hanging-basket, it will quickly grow over the edges and becomes a beautifui sight. $50 \mathrm{c}$ for $3, \$ 1.50$ per doz.

Snails, $50 \mathrm{c}$ doz.

No'TE: See Lilies in Groups at Special Prices on Page 12.

\section{PLANTING}

S(Il. AND PLANTING. The best soil for aquatic plants is a mixture of three parts of good garden soil with one part well-rotted cow-manure. Bone-meal is not desirable unless mixed with the soil (1 quart to the bushel) several months before use. Blood-meal is a good commercial fertilizer and may be used to feed plants that appear to have exhausted their soil.

New manure or blood-meal should be given hardy Waterlilies each year and new soil every two or three years.

Waterlilies should be set with the crown of the plant just beneath the surface of the soil, which is then covered with an inch of sand to keep the water clean. Any depth of water above plants from 6 inches to 2 feet will do. Full sunlight on the pool is very desirable for the growth and formation of blossoms. 
At least one cubic foot of soil should be allowed for each Waterlily, and more if possible. To obtain satisfactory growth in boxes they must be large enough to provide plenty of nourishment. A single plant in a box 2 feet square and 8 to 10 inches deep, filled with proper soil, will develop remarkable blooms. Use any lumber but redwoci.

The green scum which appears in the pool at intervals is a vegetable growth resulting from the exposure of fresh water, new soil and fertilizer to the sunlight. It usually disappears in a short time with the assistance of a few snails and plenty of plants. The use of chemicals is not advisable on account of probable injury to the fish and plants. Changing water that has become green generally prolongs the condition. The old water should clear up in a short time without further attention.

PLAN'TING-TIME. Hardy Waterlilies may be planted after the middle of April, (Calif. any month) as at that time new leaves appear in the ponds. Half-dormant roots are shipped until May, and after that growing plants. Tropical varieties may be shipped after the last week in May to Calif. Plants to the east not until June. Tropical Lilies make remarkable growth, and when well fertilized, bloom within several weeks after planting. continuing to produce their enormous flowers until late in the fall. They may also be grown in a sunroom or conservatory pool, blooming the year round with the aid of occasional rations of blood-meal pushed under the soil. It is to be noted that young tropical Lilies have a tendency to become dormant if planted out in too cold, deep or shaded water; but if the plants are removed to a warm, sunny location they usually start to grow again.

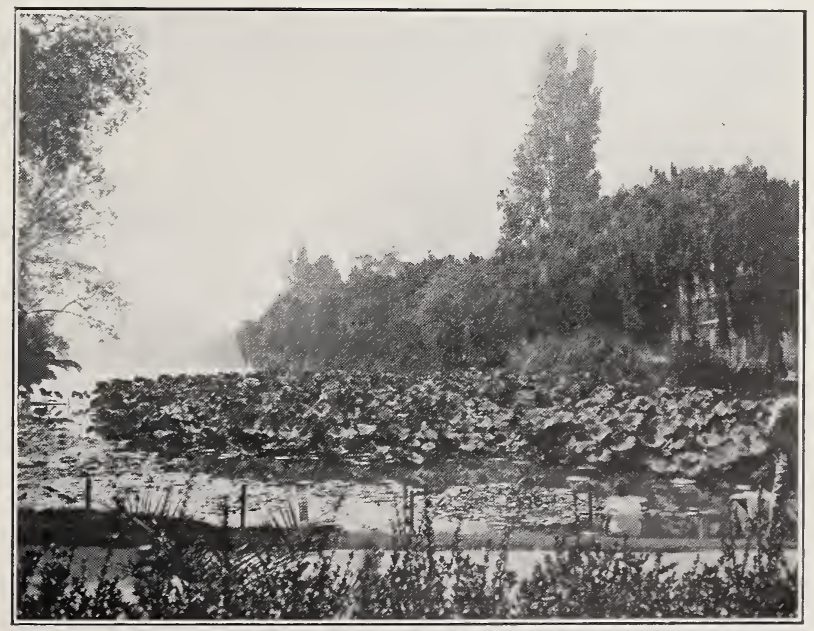

A Touch of the Orient--Our Iotus Beds 
FISH AND SNAIIS. Since the first question that arises when the new pool is suggested concerns the effect it will have on the mosquito population, it is well to remove any doubts by the assurance that the favorite food of many kinds of small fishes is the larva, or wriggler, which hatches from the egg of the mosquito. It is impossible to have mosquitoes when you have plenty of fish.

Fish or Snails should not be added to a new cement pool until after the water has stood for one week or 10 days and then changed, so as to carry out all cement poison.

The small black aphids which infest the leaves and stems above water should be washed off with the hose so that the fish can destroy them.

TUB CULTURE. It is entirely practical and satisfactory to grow Waterlilies, Jotus, and aquatics in tubs, half-barrels, or any container 2 feet or more across that will hold water. Prepare soil same as for any pool.

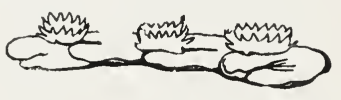

\section{WINTER CARE}

In Calif. leave all lilies as they are planted in pool. In the East or North the pool should be drained and filled with straw or any covering that may keep them from freezing, or take the bulbs up and put them in the cellar in damp sand so that they will not freeze, planting back in pool in spring about the time you would plant any hardy vegetable in garden.

\section{TO HELP YOU MAKE UP YOUR ORDER}

Prices are quoted net. All goods travel at purchaser's risk and expense.

Our Specialty-Waterlilies and Aquatic Plants. Also a complete line of Imported and Local Canaries, Aviary Birds, Parrots, Gold Fish, Globes, Cages, Pool Statuary, Plastic and Art Goods, Wrought Iron, Garden Furniture, Nursery Stock and everything for the garden.

SHIPPING. All plants will be packed with the best of care to secure safe transit, but under no circumstances do I undertake responsibility for delay or damage to goods during transit. 


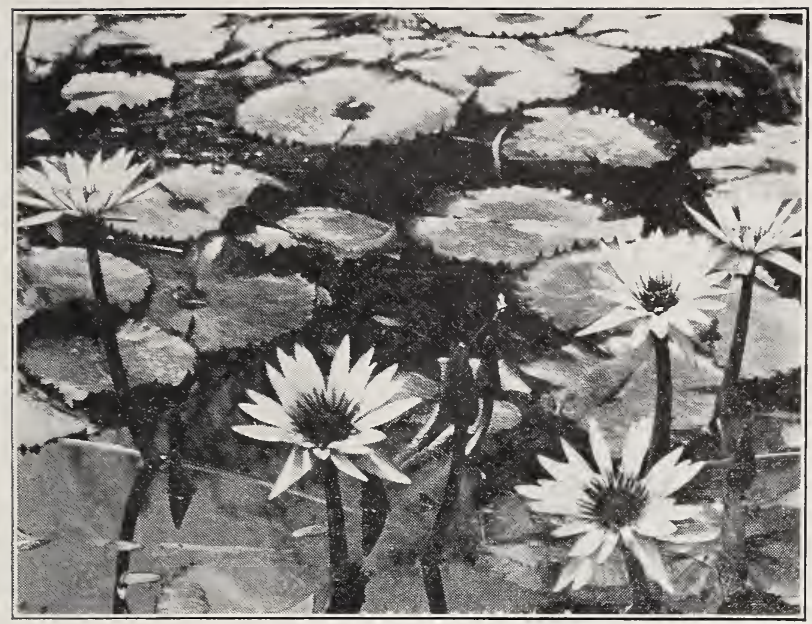

William Stone, One of the Best

Same as C. W. Ward, Except Color

PARCEL POST. Small plants can be sent by parcel post, but delays occur very often. Beyond the 3rd zone it is not only more satisfactory but even cheaper to send by express. I do not prepay postage, therefore please allow sufficient extra to pay postage; any money in excess will be returned.

CANADIAN CUSTOMERS should secure a permit from the Destructive Insect and Pest Act Advisory Board, Dept. of Agriculture, Ottawa, which permit will cover the importation of aquatic plants. Send the number of the permit to me, thus avoiding delay in delivery of shipments.

I GUARANTEE my plants to be in good condition when shipped; but I cannot be responsible for results. Unusual climatic conditions and disregard of planting instructions are entirely beyond my control.

COMPLAINTS, if any, as to quality of goods, etc., can be entertained only when made immediately on receipt of goods.

PLACE ORDER EARLY for spring delivery and prevent delay of shipment or planting.

SUBSTITUTIONS. Sometimes-especially toward the end of the shipping season-I am unable to supply strong plants of some varieties. In such cases, unless otherwise instructed, I will substitute a variety as near like the one ordered as possible, of equal or greate: value. 


\section{LILIES IN GROUPS}

The following collection of lilies are considered the very best we have to offer in the way of color and blooming. In grouping them as shown below we can offer you a marked saving.

\section{GROUP NO. 1}

1 Comanche, Copper Red $\$ 3.50$

1 Chromatella, Yellow

1 Somptuosa, Rose Pink 3.50

\section{Total $\$ 8.50$}

All for

\section{GROUP NO. 2}

1 Chromatella, Yellow $\$ 1.50$

1 Paul Hariot, Apricot Pink .................................. $\quad 2.50$

1 Aurora Semi-Dwarf ............................................. $\quad 1.50$

1 C. W. Ward, Tropical ...................................... 2.50

\section{Total $\$ 8.00$}

All for $\$ 6.50$

\section{GROUP NO. 3}

1 C. W. Ward, Pink $\$ 2.50$

1 W. Stone, Blue Purple

2.50

1 Masanello, Rose Pink

3.50

1 Comanch, Copper Red

3.50

1 Gygmy Heluola, Yellow

1 Marlac, White

1.00

Total $\$ 13.75$

All for $\$ 11.95$

\section{GROUP NO. 4}

1 Sun Rise, Yellow $\$ 7.50$

1 Escoubouche, Dark Red

1 Consueror, Carmine Red with White

1 Comanche, Copper Red

1 W. Stone, Blue Purple

2.50

1 C. W. Ward, Pink

2.50

1 Aurora, Copper Red, Semi-Dwarf

1.50

Total $\longdiv { \$ 2 8 . 5 0 }$

All for $\$ 24.50$

We also carry a full line of Birds, Pets, Cages and Supplies, Garden Furniture, Pool Ornaments, Imported Gnomes (or Elf Men), Pottery and Shrubs. 